\title{
Analytical study on the perceived levels of work life balance experienced by operational staff of five star hotels of Delhi
}

\author{
Paresh Bali ${ }^{1, *}$, Kavita Khanna ${ }^{2}$, R. K. Gupta ${ }^{3}$ \\ ${ }^{1,2}$ Assitant Professor, Amity University, Uttar Pradesh, ${ }^{3}$ Professor, Delhi University, New Delhi, India
}

*Corresponding Author:

Email: pbali@amity.edu

\begin{abstract}
Introduction: The objective of the study was to measure and compare the levels of work life balance of operational staff of the four main departments of five star hotels in Delhi. To analyze the levels of work life balance and compare whether there were a significant differences in the levels of work life balance of operating staff from different operational department of five star hotels of Delhi.

Materials and Methods: The study is based on the data collected from 121 employees of five star hotels of Delhi, who work in four operational departments of hotels. The data was collected with the help of self-administered questionnaire and analyzed through SPSS software.

Result: Analysis of data proved that there was a significant difference in the levels of work life balance experienced by operational staff of five star hotels, highest level of work life balance was experienced by staff of front office and lowest for the of food production department. The result followed a similar pattern for the four dimension of work life balance namely quality time, involvement, satisfaction and health.

Conclusion: There was no equality in the levels of work life balance of operating staff of five star hotels, the levels of work life balance was differential among departments, it was highest for the staff working in front office department and then a gradual decrease was noted with each subsequent department namely housekeeping, food service and food production. The differences could be due to factors like shift timings, break shifts etc.
\end{abstract}

Keywords: Work life balance, Five star hotels, Delhi.

\section{Introduction}

It is a well-known fact that hotel's operational staff or employees have to work long hours \& need to perform heavy work, working in break shifts or in any shift in a day is a common practice and they have to deal with ever demanding and difficult customers (Hsieh et al., 2004; Sarabahksh et al., 1989), it was noted that hotel industry do not have effective human resource practices and employees had to face lot of stress due to the issues stated above stretched working hours, irregular work schedules and job insecurity (Karatepe, 2008; Deery and Shaw, 1999; and Rowley and Purcell, 2001), specifically in Indian hotel industry the staff had to work longer than usual shifts and the compensation is also meagre. The coupled effects of these factors lead to issues like demotivation, over stress and work life imbalances. The paper is focused on the issue of work life imbalance, work life imbalance increase stress that lower the level of performance (Fair weather, 2013) affecting the overall performance of organization on the other hand work life balance creates satisfied employees which lead to improvement in performance (Hall and Parker, 1993; Mason, 1991; Deery \& Jago, 2009). Operating staff of hotels work at irregular times and stretched work hours that has a significant impact on physical, psychological and emotional wellbeing of employees (Presser. 2004) working on holidays and weekend complicate the matter further (Almeida, 2004). Higher job demands with low control on job with no supportive measure from hotel to manage work life balance result in higher level of stress (Flora F T Chiang, 2010). In India due to oversupply of work force and lower wages, staff have to work longer in a given compensation this aggravate the issue of work life imbalance.

Apart from work nature or work characteristics of hotel operations, factors like age, stage in life cycle also has an influence on work life imbalance (Macky \& Boxall, 2008). For instance people with younger children or having parents at home experience more work life imbalance. Work life balance is an important issue for both employee and employers. Work life balance improves the performance of employee (Karatepe \& Bekteshi, 2008) \& increases employee's commitment; improve retention, productivity and mental health (Gallinsky, 2005). This again proved by the researchers that work life facilitation provided by companies was positively related to job satisfaction and improved commitment (Aryee et al 2005; Tompson \& Werner, 1997). The paper tries to measure and analyze the levels of work life balance of operating staff from the four main department namely front office, housekeeping, food service and food production, of the five star hotels of Delhi. The four departments are the core functional departments of Hotels and perform the primary functions that result in to achieving the objectives of the organization. The paper measured and analyzed the levels of work life balance of the operation staff of the four core departments so as to ascertain in which department there is lack of work life imbalance and the order in which the levels of work life balance decreases. 


\section{Materials and Methods}

As per the detailed discussion it was noted that working in hotel industry is tedious and challenging also it is difficult to maintain a good balance between work and life for an hotelier, it was also noted that with age the demands from individual and his roles and responsibilities changes with time. The objective of the study was to measure the levels of work life balance experienced by operational staff of five star hotels and analyze were there any defined pattern in the levels of work life balance and the department. Work life balance was measured on a construct made up of four dimensions.

Following were the objectives for the research.

1. To measure the perceived levels of work life balance experienced by operating staff of five star hotels of Delhi Capital Region.

2. To analyze the levels of work life balance experienced by operating staff from different core departments.

3. To find out were there any well-defined pattern in the levels of work life balance and the department of operating staff.

The study was based on the data collected by the author from the operating staff five star hotels of Delhi, the four departments were food production, $\mathrm{f} \& \mathrm{~b}$ service, front office and housekeeping. The data was collected from 121 respondents through a questionnaire developed from the results of explorative study conducted in the year 2015 by the author, with sample size 30 that included academicians, HR managers or training managers of the hotels and supervisors of the hotels and the review of literature. Four dimensions were noted to measure the levels of work life balance; they were quality time, involvement, satisfaction and health. The questionnaire had statements on which respondents were asked about their agreement or disagreement. For analysis a 5 point scale was employed with labels $(1=$ strongly disagree, $2=$ somewhat disagree, $3=$ not sure, $4=$ somewhat agree and $5=$ fully agree). The respondents were required to give their response on the basis of their own experience and opinions. Every dimension was assigned equal weightage and total score was calculated to find out the levels of work life balance. Each dimension was assigned the score of 100 and maximum score of work life balance was 400. In the next step the levels of work life balance were compared and tested using one way ANOVA and Tukey HSD test. More than 200 questionnaires were distributed by hand and out of it 125 were received back and 121 were found to be complete in all respect.

\section{Result}

Out of total $66.11 \%$ participants were male and $33.89 \%$ females, majority of the staff members were males. Majority of the respondents $38.83 \%$ were from the age group of 25-30 years, and then there was a gradual decrease in the numbers with increase in the age, only $2.49 \%$ were from the age group of $45-50$ years. This may be due to the fact of career progression with increase in the age. $69.42 \%$ were married and $30.58 \%$ were single. $33.05 \%$ respondents were from food production, followed by $26.45 \%$ participants were from front office, $24.79 \%$ participants were from $\mathrm{f} \& \mathrm{~b}$ service and rest $15.71 \%$ were from the house keeping department (Table-1). Table 2 provide the result of ANOVA test and Table 3 presents the result for the Tukey HSD test to find the order of the levels of the four dimensions of the work life balance experienced by the operating staff of the four departments of the hotel. It can be stated that operating staff from housekeeping and front office department spent equal quality time which is better than the time spent by supervisors of $f \& b$ service and food production department. Data indicate that the staff of front office enjoys highest levels of involvement in their personal life, followed by staff of $f \& b$ service, the lowest levels of involvement were found for staff of food production department. It was found that staff from Front office department experience highest level of satisfaction in comparison to supervisors of all the other departments, there is a very marginal difference in levels of satisfaction experienced by the staff of the other three departments. As per the analysis of data presented, indicate that the level for the dimension of health is almost equal for all the staff only in case of food production department the levels are at a lower side.

Table 1: Demographic data for the participants

\begin{tabular}{|l|c|c|c|c|}
\hline \multicolumn{1}{|c|}{ Gender } & Frequency & Percent & Valid Percent & Cumulative Percent \\
\hline Male & 80 & 66.11 & 66.11 & 66.11 \\
\hline Female & 41 & 33.89 & 33.89 & 33.89 \\
\hline Total & 121 & 100 & 100 & \\
\hline Age Group & Frequency & Percent & Valid Percent & Cumulative Percent \\
\hline 25-30 Yrs & 47 & 38.83 & 38.83 & 38.83 \\
\hline 30-35 Yrs & 31 & 25.61 & 25.61 & 64.44 \\
\hline 35-40 Yrs & 29 & 23.97 & 23.97 & 88.41 \\
\hline 40-45 Yrs & 11 & 9.1 & 9.1 & 97.51 \\
\hline $45-50$ Yrs & 3 & 2.49 & 2.49 & 100 \\
\hline
\end{tabular}




\begin{tabular}{|l|c|c|c|c|}
\hline Total & 121 & 100 & 100 & \\
\hline Marital Status & Frequency & Percent & Valid Percent & Cumulative Percent \\
\hline Married & 84 & 69.42 & 69.42 & 69.42 \\
\hline Single & 37 & 30.58 & 30.58 & 100 \\
\hline Total & 121 & 100 & 100 & \\
\hline Marital Status & Frequency & Percent & Valid Percent & Cumulative Percent \\
\hline $\begin{array}{l}\text { Food } \\
\text { Production }\end{array}$ & 40 & 33.05 & 33.05 & 33.05 \\
\hline F \& B Service & 30 & 24.79 & 24.79 & 57.84 \\
\hline Front Office & 32 & 26.45 & 26.45 & 84.29 \\
\hline House Keeping & 19 & 15.71 & 15.71 & 100 \\
\hline Total & 121 & 100 & 100 & \\
\hline
\end{tabular}

Table 2: Result for ANOVA test for the dimensions of work life balance and the four department of the Hotel

\begin{tabular}{|c|c|c|c|c|c|c|}
\hline  & & $\begin{array}{c}\text { Sum of } \\
\text { Squares }\end{array}$ & df & $\begin{array}{c}\text { Mean } \\
\text { Square }\end{array}$ & $\mathbf{F}$ & Sig. \\
\hline \multirow[t]{3}{*}{ Quality time } & Between Groups & 5707.377 & 3 & 1902.459 & 32.79 & .000 \\
\hline & Within Groups & 6788.481 & 117 & 58.02121 & & \\
\hline & Total & 12495.858 & 120 & & & \\
\hline \multirow[t]{3}{*}{ Involvement } & Between Groups & 7126.650 & 3 & 2375.55 & 40.03 & .000 \\
\hline & Within Groups & 6943.084 & 117 & 59.3426 & & \\
\hline & Total & 14069.735 & 120 & & & \\
\hline \multirow[t]{3}{*}{ Satisfaction } & Between Groups & 15693.341 & 3 & 5231.114 & 86.28 & .000 \\
\hline & Within Groups & 7093.774 & 117 & 60.63055 & & \\
\hline & Total & 22787.115 & 120 & & & \\
\hline \multirow[t]{3}{*}{ Health } & Between Groups & 7212.637 & 3 & 2404.212 & 26.12 & .000 \\
\hline & Within Groups & 10768.090 & 117 & 92.03496 & & \\
\hline & Total & 17980.728 & 120 & & & \\
\hline \multirow{3}{*}{$\begin{array}{l}\text { Total score for } \\
\text { work life balance }\end{array}$} & Between Groups & 5775.134 & 3 & 1925.045 & 73.82 & .000 \\
\hline & Within Groups & 3050.885 & 109 & 26.07594 & & \\
\hline & Total & 8826.020 & 112 & & & \\
\hline
\end{tabular}

Table 3: Results of Tukey HSD for the four dimension of work life balance

\begin{tabular}{|c|c|c|c|c|c|c|c|c|c|c|}
\hline Tukey HSD & \multirow[t]{2}{*}{$\mathbf{N}$} & \multicolumn{2}{|c|}{$\begin{array}{c}\text { Dimension } \\
\text { Quality Time } \\
\text { Subset for alpha }= \\
0.05\end{array}$} & \multicolumn{3}{|c|}{$\begin{array}{l}\text { Dimension Involvement } \\
\text { Subset for alpha }=0.05\end{array}$} & \multicolumn{2}{|c|}{$\begin{array}{c}\text { Dimension } \\
\text { Satisfaction, } \\
\text { Subset for } \\
\text { alpha }=\mathbf{0 . 0 5}\end{array}$} & \multicolumn{2}{|c|}{$\begin{array}{c}\text { Dimension } \\
\text { Health, } \\
\text { Subset for } \\
\text { alpha }=\mathbf{0 . 0 5}\end{array}$} \\
\hline Department & & 1 & 2 & 1 & 2 & 3 & 1 & 2 & 1 & 2 \\
\hline Food Production & 40 & 50.11 & & 53.15 & & & 57 & & 73.44 & \\
\hline F \& B Service & 30 & 52 & & & 60.12 & & 59.06 & & & 83.25 \\
\hline House Keeping & 19 & & 59.69 & & 63.26 & & 62.81 & & & 91.22 \\
\hline Front Office & 32 & & 65.21 & & & 73.59 & & 85.79 & & 91.86 \\
\hline Sig. & & 0.611 & 0.056 & 1 & 0.494 & 1 & 0.053 & 1 & 1 & 0.285 \\
\hline
\end{tabular}

Table 4: Results of Tukey HSD for the dimension of work life balance

\begin{tabular}{|c|c|c|c|c|}
\hline \multirow{3}{*}{$\begin{array}{c}\text { Tukey HSD } \\
\text { Core Department of work }\end{array}$} & \multirow{3}{*}{$\mathbf{N}$} & & & \\
\hline & & \multicolumn{3}{|c|}{ Subset for alpha $=\mathbf{0 . 0 5}$} \\
\hline & & 1 & 2 & 3 \\
\hline Food Production & 40 & 47.22 & & \\
\hline House Keeping & 19 & & 53.72 & \\
\hline F \& B Service & 30 & & 54.62 & \\
\hline Front Office & 32 & & & 66.32 \\
\hline Sig. & & 1.000 & 1.000 & 1.000 \\
\hline
\end{tabular}




\section{Discussions}

The data was collected from the participants on the four dimensions namely quality time, involvement, satisfaction and health. based on the overall score of these four dimensions levels of work life balance was calculated, the data analysis though ANNOVA \& Tukey HSD test indicated that staff of front office and housekeeping have better levels of work life balance as compared to work life balance levels of staff from food production and $f \& b$ service. In case of Involvement in personal and family life it was found that the staff members from front office department have the highest level and lowest levels were recorded for food production department rest two departments lay in between. Whereas for the dimension of satisfaction front office staff has the highest levels in comparison to any other staff members from any other department and for the dimension of health, except staff from food production department rest all the other staff member had a satisfactory levels. On the overall perceived levels of work life balance it was noted that highest levels were for front office followed by housekeeping and $f \& b$ service and least for the staff members of food production department.

\section{Conclusions}

Study concludes that there is a clear relationship between the department of work and levels of work life balance experienced by the staff of operational departments of hotels of Delhi. Out of the four main functional department of hotels namely food production, food service, housekeeping and front office the staff working in front office have the highest level of work life balance and least levels were for the food production department. The main reasons could be, and proved with further research, the break shifts and long working hours in food production department as there are straight shifts with regular working hours in the front office, secondly it could be due to the reason that in food production department the work is heavy and more demanding in comparison to the nature of work in the front office department.

\section{References}

1. Adams, G.A., King, L.A., \& King, D.W. Relationships of job and family Involvement, family social support, and work-family conflict with job and life Satisfaction. Journal of Applied Psychology. 1996;81(4):411-420.

2. Barnett, R. C. A new work-life model for the twenty-first century. Annals of the American Academy of Political and Social Science. 1999;56(2):143-158.

3. Beauregard T. A. \& Henry L. C. Making the link between work-life balance practices and organizational performance. Human Resource Management Review, 2009;19:9-22.

4. Daniels, L., \& McCarraher, L. (2000) The work-life manual. London, England: Industrial Society.

5. Deery, M.A., and Shaw, R.N. An Investigation of the Relationship between Employee Turnover and
Organisational Culture. Journal of Hospitality and Tourism Research. 1999;23(4):387-400.

6. Harris, Candice, and Pringle, Judith (2007). Work-Life Balance: Who is the Target for this Silver Bullet? Paper for presentation at Inaugural Work-Life Research Workshop, Australian Centre forResearch in Employment and Work (ACREW), Melbourne, 3 December.

7. Karatepe, O.M., \& Bekteshi, L. Antecedents and outcomes of work-family facilitation and family-work facilitation among frontline hotel employees. International Journal of Hospitality Management. 2008;27:517-528.

8. Neal, M.B. and Hammer, L.B. (2007), Working Couples Caring for Children and Aging Parents: Effects on Work and Well-Being, Lawrence Erlbaum, Mahwah, NJ.

9. Rowley, G. and Prcell, K. As Cooks Go, She Went: Is Labour Churn Inevitable?, International Journal of Hospitality Management. 2001;20 (2):163-185.

10. Sturges, J. \& Guest, D. Working to live or living to work? Work/life balance early in the career. Human Resource Management Journal. 2004;14:5-20.

11. Xiao, Qu, and O'Neill, John W. Work-Family Balance as a Potential Strategic Advantage: A Hotel General Manager Perspective. Journal of Hospitality and Tourism Research. 2010;34(4):415-439. 